\title{
Impact of Social Media on Modern Society: An Empirical Research of Haryana
}

\author{
Sujata, Assistant professor, Department of Computer Science, Pt. NRS Government College, \\ Rohtak, India.
}

\begin{abstract}
Social media is very useful in present scenario. It is powerful medium to circulate all informations in present time. The whole world becomes a village through social media. The study examines the impact of social media on society in Haryana. This study was conducted in Rohtak district of Haryana. The interview scheduled method was employed. In this study, 240 respondents were selected by purposive sampling. The objectives of the study were to find out the attitude of the people towards reliability of social media; to know the attitude of the people about advantages and disadvantages of social media. On the basis of this study researcher found that the youth belonged to different age, and education group indicate their varied responses on impact of social media on society.
\end{abstract}

Keywords: Social media, Interview scheduled, Global Digital Overview, Split up of Families, Hazardous for Teenager, Gossips and Rumors, Credibility

\section{INTRODUCTION}

Social media is an online platform which people use to build social relations with other people. People share their personal interest, activities and other information. It affects every part of individuals as well as society. In present scenario, many people are using their smart phones, tablets, laptops, and computers. There are many social sites such as Facebook, WhatsApp, Twitter, Linkined, Like,TikTok, YouTube, Google +, Instagram, Helo, etc. Most of people are online every time to check tweets and update status from their family members and friends. Due to the advance technology, People are accepted different lifestyle. Social media provide platform to young people to have conversation, share informations on tweets, blogs, photo sharing, video sharing, message etc. Most of the people around the world use social media and share informations to make close network. Social media allow to communicate with others, gain knowledge of different new things, develop our interests and entertainments. On the other hand, we can make use of social media to expand our knowledge in a particular field by connecting with other professionals. Social media allows to have a conservation with audiences, get customer feedback and improve the quality of a brand.

Today, social media is a dramatical revolution in the world. Most of person are on social site and present himself as a hero. In Youtube , Smule, Star maker, Tiktok, Helo and many other similar site or app which shows dream to a common people. It is the fastest medium of today to connect the universe. It is also a bond between Government and citizens. The government share information to people in few seconds through social media. it is also a powerful weapon to eradicate illiteracy. It is the main source of knowledge. These sites also very useful in various type of research. Although social media is so useful to society but also affect an individual as well as society. There are many consequences of social media. In this study, researcher studied the advantages and disadvantages of social media in a society.

\section{Social Media Statistics}

According to 'Digital 2020 Report' published on the 30th January 2020, More than 4.5 billion people are using the internet at the start of 2020. Report says that nearly 60 percent of the world's population is already online, and the total numbers of Internet users showing that surprisingly, around 49 percent of the total Internet users are active social media users. This reports stated that social media users grew by nearly 10 per cent between 2019 and 2020 . Facebook is the most popular social media platform. It comes into existence on February 4, 2004. Worldwide, there are over 2.50 billion monthly active users for December 2019. (Digital 2020: Global Digital Overview, January 30, 2020). YouTube; most well known video based social media. It has more than one billion site users for every month. Twitter has 320 million active monthly users. Whereas, WhatsApp has one billion active users. It is also shows that the users spend an average of three hours per day on social networks and messaging. (Akram and Kumar, 2017)

\section{Method AND MATERIAL}

The study concerns with impact of social media on individual as well as society. It was conducted in Rohtak district. The selection criterion of the district Rohtak was that Rohtak is the education hub.In this study, interview schedule was prepared to collect the various types of 
informations. In this study interview method was employed. The 240 respondents were selected by purposive sampling from the study area. Aiming at multiple objectives, the relevant age group 16-56 years, has been taken into consideration. There are different sources of information, which have been used for gathering the first and second hand information from the study area. The main objectives of the study were to find out the attitude of the people towards reliability of social media; to know the attitude of the people about advantages and disadvantages of social media.

\section{RESUlts AND DiscuSSION}

In order to carry out of the study of Impact of Social media on society, various stratified sampling have been taken into consideration. Keeping in view age-wise distribution of the respondents. Table 1 indicates that the majority of the respondents were within the age-group of between 16-26 years (i.e. 36.25 per cent). It indicates that respondents were quite young. Out of the 240 respondents, 28.75 per cent respondents were in the age-group of 27-36 years. On the other hand, 22.92 per cent respondents were within the agegroup of 37-46 years. Whereas, 12.08 per cent respondents were within the age-group of 47-56 years.

Table 1 Socio-Economic Details of the Respondents

\begin{tabular}{|c|c|c|c|c|}
\hline $\begin{array}{l}\text { Sr. } \\
\text { No. }\end{array}$ & Particulars & & $\begin{array}{l}\text { No. of } \\
\text { Respondents } \\
240\end{array}$ & Percentage \\
\hline \multirow[t]{4}{*}{1.} & \multirow{4}{*}{$\begin{array}{l}\text { Age } \\
\text { (in years) }\end{array}$} & $16-26$ & 87 & 36.25 \\
\hline & & $27-36$ & 69 & 28.75 \\
\hline & & $37-46$ & 55 & 22.92 \\
\hline & & $47-56$ & 29 & 12.08 \\
\hline \multirow[t]{3}{*}{2.} & \multirow[t]{3}{*}{ Education } & Upto Primary & 27 & 11.25 \\
\hline & & Matric & 132 & 55.00 \\
\hline & & $\begin{array}{l}\text { Graduation \& } \\
\text { Above }\end{array}$ & 81 & 33.75 \\
\hline \multirow[t]{4}{*}{3.} & \multirow{4}{*}{$\begin{array}{l}\text { Source of } \\
\text { Income } \\
\text { *Multiple } \\
\text { Responses }\end{array}$} & $\begin{array}{l}\text { Agriculture/ } \\
\text { Labour }\end{array}$ & 111 & 46.25 \\
\hline & & Petty business & 66 & 27.50 \\
\hline & & Govt. Job & 27 & 11.25 \\
\hline & & $\begin{array}{l}\text { House hold } \\
\text { activities }\end{array}$ & 51 & 21.25 \\
\hline
\end{tabular}

Keeping in view, the educational level of the respondents, 11.25 per cent of the respondents who have studied upto primary class. Whereas, 55 per cent of the respondentss were matriculate and 33.75 per cent of the people were graduate and above. As far as their source of income is concerned, the majority (46.25 per cent) of the respondents, dependent on agricultural practices, either in the form of labourers or as tenants. Whereas, 27.5 per cent of the respondents have been engaged in petty business too. Only 11.66 per cent of the respondents were in government jobs. Rests of the respondents engaged in house hold activities.
In order to have reliability of social media, varied responses of the respondents (Table 2) indicate different response, by forming opinion on Likert scale. 8.75 per cent of the respondents have strongly agreed, while most of the respondents (51.25 per cent) showed their view point 'agreed'. The percentage figure of 'no opinion' has been 7.5 per cent. While 21.25 per cent disagree and 11.25 per cent of the respondents were strongly disagree. It is quite obvious that the majority of the respondents believe that the reliability of social media.

Table 2-Attitude of Respondents towards Reliability of Social Media

\begin{tabular}{|c|c|c|c|}
\hline $\begin{array}{l}\text { Sr. } \\
\text { No. }\end{array}$ & Response & $\begin{array}{c}\text { No. of } \\
\text { Respondents }\end{array}$ & Percentages \\
\hline 1. & Strongly agree & 21 & 8.75 \\
\hline 2. & Agree & 123 & 51.25 \\
\hline 3. & No. Response & 18 & 7.50 \\
\hline 4. & Disagree & 51 & 21.25 \\
\hline 5. & $\begin{array}{l}\text { Strongly } \\
\text { disagree }\end{array}$ & 27 & 11.25 \\
\hline \multicolumn{2}{|c|}{ Total } & 240 & 100 \\
\hline
\end{tabular}

Referring to the table 3, which indicate age-wise attitude towards reliability of social media, we observe that the respondents belonging to age-group 16 to 26 years indicated that the 11.49 per cent of the respondents were 'strongly agreed' and 60.92 per cent of the respondents admitted that they are agreed with this perception. On the other hand, 13.79 per cent of the respondents have answered in disagree, while 9.20 per cent of the respondents were strongly disagree. Lastly, 4.60 per cent of the respondents have failed to give any type of response. Hence, it is obvious that the 36.25 per cent of the respondents have been given a considerable subjectivity in this context.

Table 3 Age -Wise Attitude of Respondents towards Reliability of Social Media

\begin{tabular}{|c|c|c|c|c|c|c|c|}
\hline \multirow{2}{*}{$\begin{array}{l}\text { S } \\
\text { r. }\end{array}$} & \multirow{2}{*}{$\begin{array}{c}\text { Age (in } \\
\text { N }\end{array}$} & \multicolumn{5}{|c|}{ Rears) } \\
o. & & $\begin{array}{c}\text { Stron } \\
\text { gly } \\
\text { agree }\end{array}$ & Agree & $\begin{array}{c}\text { No. } \\
\text { Respo } \\
\text { nse }\end{array}$ & $\begin{array}{c}\text { Disag } \\
\text { ree }\end{array}$ & $\begin{array}{c}\text { Stron } \\
\text { gly } \\
\text { disag } \\
\text { ree }\end{array}$ & \\
\hline 1. & $16-26$ & 10 & 53 & 4 & 12 & 8 & $87(10$ \\
& & $(11.49$ & $(60.92)$ & $(4.60)$ & $(13.79$ & $(9.20)$ & $0)$ \\
\hline 2. & $27-36$ & 5 & 35 & 5 & 15 & 9 & 69 \\
& & $(7.25)$ & $(50.72)$ & $(7.25)$ & $(21.74$ & $(13.04$ & $(100)$ \\
\hline 3. & $37-46$ & 4 & 24 & 5 & 16 & 6 & 55 \\
& & $(7.27)$ & $(43.64)$ & $(9.09)$ & $(29.09$ & $(10.91$ & $(100)$ \\
\hline 4. & $47-56$ & 2 & 11 & 4 & 8 & 4 & $29(10$ \\
& & $(6.90)$ & $(37.93)$ & $(13.79$ & $(27.59$ & $(13.79$ & $0)$ \\
\hline & & & & ) & ) & ) & \\
\hline
\end{tabular}

*Percentages are given in brackets 
Within the age-group of 27 to 36 years, 7.25 per cent of the respondents have given their answer as 'strongly agree' and 50.52 per cent of the respondents have given their answers as 'agree'. On the other hand, 21.74 per cent of the respondents have given as 'disagree' and 13.04 per cent of the respondents have strongly disagreed. Lastly, there were 7.25 per cent of the respondents, who have failed to give any response in this context.

Within the age-group of 37 to 46 years, it has been observed that the 7.27 per cent of the respondents have been given their answer as 'strongly agree' and 43.64 per cent of respondents admitted the reliability of social media. Whereas, 29.09 per cent of the respondent have given their answers as 'disagree' and 10.91 per cent of the respondent were strongly disagreed with this perception. In this context 9.09 per cent of the respondents have failed to form any opinion on this 'perception'.

Within the age-group of 47-56 years it has been observed that the 6.9 per cent of the respondents were strongly agreed and 37.93 per cent of the respondents were strongly agree. Whereas, 27.59 per cent of the respondents indicated their disagree attitude and 13.79 percent of the respondents were strongly disagreed on this perception. Lastly, 13.79 per cent figure indicated their 'Nil' response on this 'perception'. Hence, it is quite obvious that the 12.08 per cent of the respondents have responded their views in a different way. Hence, it is quite obvious that the attitude towards reliability of social media has been very subjective. Most of the youth were agreed with the reliability of social media. Whereas, a considerable number of older people were disagreed with this perception.

Table 4 Education-Wise Attitude of Respondents towards Reliability of Social Media

\begin{tabular}{|c|c|c|c|c|c|c|c|}
\hline \multirow{2}{*}{$\begin{array}{l}\text { S } \\
\text { r. } \\
\text { N } \\
\text { o. }\end{array}$} & \multirow{2}{*}{$\begin{array}{c}\text { Education } \\
\text { Level }\end{array}$} & \multicolumn{5}{|c|}{ Responses } & \multirow{2}{*}{ Total } \\
\hline & & $\begin{array}{c}\text { Stron } \\
\text { gly } \\
\text { agree }\end{array}$ & Agree & $\begin{array}{c}\text { No. } \\
\text { Respo } \\
\text { nse }\end{array}$ & $\begin{array}{c}\text { Disag } \\
\text { ree }\end{array}$ & $\begin{array}{c}\text { Stron } \\
\text { gly } \\
\text { disag } \\
\text { ree }\end{array}$ & \\
\hline 1. & $\begin{array}{c}\text { Upto } \\
\text { primary }\end{array}$ & $\begin{array}{c}6 \\
(22.23 \\
)\end{array}$ & $\begin{array}{c}9 \\
(33.33)\end{array}$ & $\begin{array}{c}5 \\
(18.52 \\
)\end{array}$ & $\begin{array}{c}4 \\
(14.81 \\
)\end{array}$ & $\begin{array}{c}3 \\
(11.11 \\
)\end{array}$ & $\begin{array}{c}27(10 \\
0)\end{array}$ \\
\hline 2. & Matric & $\begin{array}{c}10 \\
(7.58)\end{array}$ & $\begin{array}{c}63 \\
(47.72)\end{array}$ & $\begin{array}{c}9 \\
(6.82)\end{array}$ & $\begin{array}{c}32 \\
(24.24 \\
)\end{array}$ & $\begin{array}{c}18 \\
(13.64 \\
)\end{array}$ & $\begin{array}{c}132 \\
(100)\end{array}$ \\
\hline 3. & $\begin{array}{c}\text { Graduation } \\
\text { \& Above }\end{array}$ & $\begin{array}{c}5 \\
(6.17)\end{array}$ & $\begin{array}{c}51 \\
(62.96)\end{array}$ & $\begin{array}{c}4 \\
(4.94)\end{array}$ & $\begin{array}{c}15 \\
(18.52 \\
)\end{array}$ & $\begin{array}{c}6 \\
(7.41)\end{array}$ & $\begin{array}{c}81(10 \\
0)\end{array}$ \\
\hline & Total & $\begin{array}{c}21 \\
(8.75)\end{array}$ & $\begin{array}{c}123 \\
(51.25)\end{array}$ & $\begin{array}{c}18 \\
(7.5)\end{array}$ & $\begin{array}{c}51 \\
(21.25 \\
)\end{array}$ & $\begin{array}{c}27 \\
(11.25 \\
)\end{array}$ & $\begin{array}{r}240 \\
(100)\end{array}$ \\
\hline
\end{tabular}

*Percentages are given in brackets
Keeping in view education-wise attitude of the respondents towards reliability of social media (Table 4), a varied responses have been observed in this context. Among upto primary respondents, we have observed that the 22.23 per cent of the respondents have been strongly agreed and 33.33 per cent respondents were agreed with this perception. On the other hand, 14.81 per cent of the respondents show their 'disagree' attitude and 11.11 per cent respondents are strongly disagreed toward this perception. Further, 18.52 per cent of the respondents have not responded at all. Hence, we have observed that the most of the respondents, who have studied upto primary, have shown high subjective thinking in this context.

In the case of the $10^{\text {th }}$ class passed respondents, amongst all these respondents, we have observed that the 47.72 per cent of the respondents have 'agreed' and 7.58 per cent respondents were strongly agreed attitude towards reliability of social media. On the other hand, 24.24 per cent of the respondents have 'disagreed' and 13.64 percent respondents were strongly disagreed on this issue. Lastly, there were 6.82 per cent of the respondents, who have failed to give any response in this context.

In case of graduation \& above respondents, we have observed that the majority of respondents (62.96 per cent) have been agreed and 6.17 per cent of the respondents were strongly agreed on this perception, whereas, 18.52 per cent of the respondents have been 'disagreed' and 7.41 per cent of the respondents were strongly disagreed on this perception. Lastly, 18.52 per cent of the respondents have not responded at all. Hence, we observed that the most of the educated respondents have responded with varied attitude towards reliability of social media.

On the basis of attitude of the respondents towards advantages of social media various response as mentioned in table 4. Social media is very useful to 'improve their knowledge' in various fields. In this connection, 78.75 percent respondents were agreed on this perception.

Social media is very easy to connect anywhere. Any person can connect with anyone in the world in a few moments. So it is very useful and easy to maintain the relations to family members, friends, and professionals. Most of the respondents (95 per cent) were favoured on this perception.

Table 5 -Attitude of Respondents towards Advantages of Social Media

\begin{tabular}{|c|c|c|c|}
\hline $\begin{array}{c}\text { Sr. } \\
\text { No. }\end{array}$ & Response & $\begin{array}{c}\text { No. Of } \\
\text { Respondents }\end{array}$ & Percentages \\
\hline 1. & Improve knowledge & 189 & 78.75 \\
\hline 2. & Easiest connection & 228 & 95.00 \\
\hline 3. & Helpful in education & 211 & 87.92 \\
\hline 4. & Profitable in business & 156 & 65.00 \\
\hline 5. & $\begin{array}{c}\text { Friendly in making } \\
\text { carrier }\end{array}$ & 123 & 51.25 \\
\hline 6. & $\begin{array}{c}\text { Bond between Govt. } \\
\text { and Citizen }\end{array}$ & 177 & 73.75 \\
\hline \multicolumn{2}{|c|}{ Total } & 240 & 100 \\
\hline
\end{tabular}

*Multiple responses 
Perception of the respondents toward advantage of social media is very 'helpful in education'. 87.92 per cent of the respondents who were responded on this perception. According to the respondents that social media is a powerful weapon to eradicate illiteracy in the world. It is very helpful in all type of education, and research also. It provides all type of data of every aspect of society.

With regard to perception, 'Profitable in Business', it has been advocated that the 65.00 per cent of the respondents have agreed with this perception. According to these respondents and elders that social media is a medium by which they learned new methods and techniques of business. They also mentioned that they enhance their business by social media.

In context to 'Friendly in making carrier' it has been observed that the 51.25 percent of the respondents were fevoured with this perception. Their views about this perception that it a guide. It provide us all type opportunities such as all type of knowledge to start a new business, preparation of all state, center as well as multinational competition exams. It also provides a platform to prove themselves. Many persons are touched the peak through social media. There are many actors, singers, artists, leaders, social workers, and craftsmen are the crop of social media.

Social media is a 'Bond between Government and Citizens'. In this context, 73.75 per cent of the respondents were responded their views on this perception. It is so easy to circulate all the Government policies, schemes, plans and others massages of government to common people. According to them, all the government activities related informations, they receive through social media. It is also returned the responses of the common people to government.

On the basis of observation, various disadvantages have been brought out in study areas of Haryana. Referring to table 6 which pertains to 'Lack of Credibility', it has been advocated that the 65 per cent of the respondents 'Agreed' with this perception. Their attitude about social media that there are many fake news and informations on social media. On the contrary, 83.75 per cent of the respondents were responding that the social media is a medium by which people spread 'Gossips and Rumors'. There many social, castism, communalism violence happened by these rumors of social media.

Due to 'Threat of Hackers', cyber criminal activities have been often noticed in the society. As a result, lost of privacy, fraud, paper leak of competition exams, website hack, transfer money from others account, theft of important data from others are everyday problem. In this context, 57.50 per cent of the respondents were agreed with this perception.
Table 6 -Attitude of Respondents towards Disadvantages of Social Media

\begin{tabular}{|c|c|c|c|}
\hline $\begin{array}{c}\text { Sr. } \\
\text { No. }\end{array}$ & Response & $\begin{array}{c}\text { No. Of } \\
\text { Respondents }\end{array}$ & Percentages \\
\hline 1. & Lack of Credibility & 156 & 65.00 \\
\hline 2. & $\begin{array}{c}\text { Gossips and rumors } \\
\text { spread soon }\end{array}$ & 201 & 83.75 \\
\hline 3. & Threat of hackers & 138 & 57.50 \\
\hline 4. & Health Issues & 165 & 68.75 \\
\hline 5. & Addiction & 213 & 88.75 \\
\hline 6. & Split up of Families & 93 & 38.75 \\
\hline 7. & Hazardous for teenager & 147 & 61.25 \\
\hline & Total & 240 & 100 \\
\hline
\end{tabular}

*Multiple responses

Social Media has affected the overall health of the youth and has created frustration, irritation, depression and dejection in the society and give rise to weaker health status. In this regard it has observed that the 68.75 per cent of the respondents have 'Agreed" with the above perception.

In context of 'Addiction' of social media, majority of the respondents ( 88.75 per cent) were agreed with this perception. Most of the respondents were accepted that they spent a lot of time on social media and they said that they have become addict of it.

Due to social media, it has been noticed that to a considerable extent split up of families and domestic violence are becoming a regular feature in the society. The perception of 'Split up of Families' - in this connection, the proportionate number of respondents i.e. 38.75 per cent indicates their 'Agree' attitude towards this perception. According to them, social media is very dangers for society. The people do not give time to their family and they always connected with false dream.

Social media is a hazardous for teenager. It has been observed that 61.25 per cent of the respondents were favoured with this perception. The teenagers are always on online. They spent their maximum time on social media. They also played very dangers games such as blue whale. Many teenagers lost their life by some dangers stunt for upload on social media

Hence, we have observed from the various tabulated figures, which have indicated the magnitude of different problematic areas of society.

\section{Conclusion}

Social media is a blessing or a curse, it is upto us to use of it for our development or for destruction. Social media is very beneficial if it is used positively. Social media provide us a platform to create new thought. Majority of the respondents for the study area, have positive attitude about reliability of social media. The youths from the study area, were admitted the credibility of social media. The majority of respondents responded that it is useful to improve our knowledge, helpful in education and research, profitable in 
business, friendly in making carrier and bond between government and public. Social media has many advantages yet it likewise has a few disadvantages which affect the society. Social Media is hazardous for children and teenagers they must be guided by elders. Everyone should use it carefully and do not share personal informations because it is so risky. Social media affect our health also. As a result, a number of health problems such as frustration, irritation, strain, and poor vision etc. Life is a beautiful gift of God and we are wasting a lot of time on social media. We should enjoy it but also aware about reality. Even after these demerits, we cannot deny the importance of social media. It is a boon for us. We should adopt the positive aspects of social media and avoid its negative effects.

\section{REFERENCE}

[1] Akram, W. and Kumar, K. (2017), "A study of Positive and Negative Effects of Social Media on Society", JCSE International Journal of Computer Sciences and Engineering, October, Vol. 5 Issue10, pp 347-354.

[2] Ahmed, Mahmoudi Sidi et al. (2008), "Detection of Abnormal Motions in Multimedia", Chania ICMIMIAUCE' 08 Workshop, Crete, Greece.

[3] A.T.M Shahjahan, K.Chisty (2014), "Social Media research and its effect on our society", International journal of Information and Communication Engineering, Vol.8, No. 6.

[4] Bharati, P., Zhang, C., \& Chaudhury, A. (2014), "Social media assimilation in firms: Investigating the roles of absorptive capacity and institutional pressures", Information Systems Frontiers, Vol. 16 (2), pp 257-272.

[5] 'Digital 2020 Report' published on the 30th January, 2020.

[6] Kapoor Kaur Kawaljeet, Tamilmani Kuttiman, Rana P. Nripendra, Patil,Pushp, Dwivedi K. Yogesh, Nerur Sridhar (2018), "Advances in Social Media Research: Past, Present and Future", Inf Syst Front, Vol. 20, PP 531-558.

[7] Krasnova, H., Spiekermann, S., Koroleva, K., \& Hildebrand, T. (2010), "Online social networks: Why we disclose", Journal of Information Technology, Vol. 25 (2), pp 109-125.

[8] Qiu, L., Rui, H., \&Whinston, A. B. (2014), "Effects of social networks on prediction markets: Examination in a controlled experiment", Journal of Management Information Systems, Vol. 30 (4), pp 235-268.

[9] Schlagwein, D., \& Hu, M. (2016), “ How and why organizations use social media: Five use types and their relation to absorptive capacity", Journal of Information Technology, Vol. 32 (2), pp 194-209.

[10] S. Shabnoor,S.Tajinder (2016), "Social Media its Impact with Positive and Negative Aspects", IJCATR, Vol. 5, Issue 2, pp $71-75$.
[11] W.Tariq, M.Mehboob, M.A.Khan and F.Ullah (2012), "The Impact of social Media and Social Networking on education and Students of Pakistan" , International Journal of Computer sciences, Vol. 9, Issue 3, July.

[12] Willium, S. (2012), "Network Security and Communication", IEEE Transaction, Vol. 31, Issue 4, pp.123-141.

\section{r}

年 